\title{
NIKOLAI RYCHKOV'S MAP OF ISKE (INNER OR OLD) KAZAN OF 4 JULY 1770
}

\author{
Kees Boterbloem ${ }^{1}$, Almaz Khabibullin ${ }^{2}$, Rawil Fakhrullin ${ }^{3}$ \\ ${ }^{1}$ History Department, University of South Florida \\ Tampa, Florida, USA \\ cboterbl@usf.edu \\ ${ }^{2}$ LLC "AvanProect" \\ Kazan, Russian Federation \\ ${ }^{3}$ Institute of fundamental medicine and biology, Kazan Federal University \\ Kazan, Russian Federation \\ kazanbio@gmail.com
}

\begin{abstract}
Research objectives: On the basis of a recently discovered map - found in the manuscript library of the Russian Academy of Sciences in St. Petersburg - of Iske Kazan's fortification made by N.P. Rychkov in 1770, this article investigates the manner in which its population protected itself against its foes in the restless era that witnessed the dissolution of the Golden Horde and the transition to the Kazan khanate. It additionally asks why in fact this map was composed.

Research materials: Combining the evidence of Rychkov's map with archaeological findings and in dialogue with the relevant historiography, the authors place the map in its historical context and ponder its significance, and suggest why this map was made in 1770 .

Results and novelty of the research: It appears that Iske Kazan's inhabitants turned to a unique manner to defend themselves against their enemies, using a wall-moat-wall design to prevent any storming by mounted troops, different from what has been hitherto thought about the ruins of this defensive structure. This manner of defending seems eminently well suited to the restless conditions prevailing in the Volga-Kama region around 1400 and the art of war as practiced in this region. The article additionally suggests why this map was made in 1770, linking it to the general desire of the Romanov government to discover much more precisely how its subjects lived their lives. This impetus was born from the introduction of the Western-European scientific mindset in Peter I's reign, which paid much closer heed to a realistic understanding of nature and culture. The Russian Academy of Sciences mounted from the 1720 s onward a host of scientific expeditions, which almost resemble voyages of discovery, to map the tsarist empire, of which Rychkov's travels formed a part. The article hints at the possibility that such fact-finding missions gradually allowed the central government in St. Petersburg to increase its power over its subject peoples.
\end{abstract}

Keywords: Golden Horde, Kazan khanate, Iske Kazan. N.P. Rychkov, Scientific Revolution, Republic of Letters, archaeology, cartography, fortification

For citation: Boterbloem K., Khabibullin A., Fakhrullin R. Nikolai Rychkov's Map of Iske (Inner or Old ) Kazan of 4 July 1770. Zolotoordynskoe obozrenie=Golden Horde Review. 2021, vol. 9, no. 3, pp. 593-610. DOI: 10.22378/2313-6197.2021-9-3.593-610

Much has been written, even in English, about the history of the Bulg(h)arTatar region (more or less the territory of the contemporary Tatar Republic Tatarstan - of the Russian Federation) $[1 ; 8 ; 11 ; 14 ; 15 ; 16 ; 38 ; 39 ; 40 ; 45 ; 48]$. 
Little of any substantial scholarship, however, has ever been published in English regarding the history of this easternmost region of Europe (as defined by Strahlenberg) before Kazan's conquest by Tsar Ivan IV in 1552 [44] $]^{1}$. Our work here is a modest contribution in this direction.

It is meanwhile true as well that many questions need further clarification regarding the subsequent, "Russian-Muscovite," pre-1800 era of Kazan and Tatar history, which has often been as much understudied as the pre-1552 era [except for 38]. In fact, the "modern" study of the former khanate began before 1800, driven by the scientific expeditions dispatched by Tsar Peter I and the Academy of Sciences, even if these were more than anything voyages of discovery (N.P. Rychkov's 1769 and 1770 trips were part of them) [3; 46]. As a sort of factfinding missions, they limited themselves mainly to a search for ethnographic curiosities, but were hindered by a lack of linguistic ability and ignorance about the local history of the places described. No one among the explorers dispatched to the "remote corners" of the Russian empire seems to have prepared by undertaking an investigation of the records of such relevant former government offices such as that of Kazan or Siberia, which had been dissolved in Peter's reign (the prikaz Kazanskogo dvortsa and the Sibirskii prikaz, of which the records are now kept at the RGADA archive in Moscow).

But at least these expeditions were rooted in some of the more fruitful approaches of the Scientific Revolution that had swept the European Republic of Letters after 1650, such as the importance of careful observation of natural processes (of which Antonie Van Leeuwenhoek's microscopic investigations are one celebrated example) [on the Scientific Revolution: 23; 37]. It might be proposed as well that a similar - and linked - desire to record nature in especially WesternEuropean iconography in precise detail exerted an influence on the travel of Rychkov and others. This meticulous style of rendering natural observations is evident in Dutch still-life paintings and even more in the work of Maria Sibylla Merian (1647-1717) and of Rachel Ruysch (1664-1750), daughter of Frederick Ruysch, whose curiosity cabinet was purchased by Peter I and brought to St. Petersburg $[9 ; 13]$. Toward 1700 , this manner of representation of nature began within the Russian empire to supersede the Orthodox-Christian and Islamic traditions that traditionally rejected realistic representation. Cornelis de Bruijn painted portraits of the tsar's family in this precise Western style in the early 1700s, and the Hague artist went on to render very precise images of some of the more outstanding landmarks of the tsar's realm, including the cityscapes of some of his townssuch as Kazan - in a pioneering effort [4]. "Scientific" map-making, too, was exemplified in the 1687 map of "North- and East Tartary" that was given to Peter Iand which clearly captured his imagination - and replaced the traditional Russian way of making maps $[25 ; 31 ; 47]$. This embrace of scientific methods and precise rendition of what is observed in nature is evidenced by N.P. Rychkov's map. Finally, the strong interest in the science behind fortifications, ballistics and military engineering, expressed most famously in the seventeenth-century works by the Frenchman Vauban and the Dutchman Coehoorn, which is palpable in European warfare in the seventeenth and eighteenth century (and which Peter I shared) is apparent from Rychkov's map [7;28; 29]. One of Coehoorn's translators was

\footnotetext{
${ }^{1}$ For Russian works about the Bulgar state, see especially [41, p. 421-561].
} 
Iakov Brius, a key moderniser among Peter's retainers. Both the Dutchman Frans Timmerman and Andrei Vinius, who had Dutch roots and read the Dutch language with ease, aided Peter I's understanding of ballistics and mathematics, and thereby, it seems, introducing him to the evolving Western-European ideas about fortifications and artillery.

Among English-language readers and Western scholars it is generally known, nonetheless, how the Chinggisid empire fell apart after its heyday in the thirteenth century, with its eastern European parts first being joined together in the Qipchak Golden Horde and then further dividing into smaller polities, a process that may have been linked to the bubonic plague pandemic (the Black Death) engulfing Eurasia toward 1350 and the subsequent unrest associated with the exploits of Timur Gurkani (Tamerlane, 1336-1405) [6; 20; 21; 22; 30; 33].

In the wake of Timur's invasion of the Volga region in pursuit of Tokhtamysh, we witness the emergence of a state on the Kama river of which Iske Kazan, some 40-50 kilometres from its drainage into the Volga, is an, or perhaps even the, important center for about half a century. Iske Kazan's flourishing was a first stage in history of the Kazan khanate that was to flourish in the middle Volga region for almost 150 years, from the early-to-mid-fifteenth to the mid-sixteenth century. Superseded by Kazan after 1440, it is unknown when Iske Kazan was altogether abandoned, although it seems to have lost a lot of its political and economic significance from about the mid-fifteenth century onward. Nonetheless, it may have still been populated by Tatars for several more centuries, and it remained a sacred locus for the Muslim populations in the region.

Since Henri Pirenne noted the importance of the rise of the city in medieval Europe, it has become a commonplace to suggest that one of the key questions regarding any pre-modern or medieval town is its role and location within the polity or polities (states) in which it developed, like Iske Kazan within the fledgling Kazan khanate [34; 35]; Rorlich makes a similar argument about the Bulgar state $[39$, p. 15]. Linked to this are usually questions about such towns' defensive capacity and fortifications. Besides being indicative of the size or significance of the city, surviving fragments and remnants of walls and moats allow us to appreciate the state of technology, especially of civil engineering, when a fortress was built. This is the case as well for Tatar cities that sport a wide array of defensive structures, which makes the study of their fortifications a fruitful and thought-provoking endeavour. Functioning from the fourteenth to the sixteenth centuries, the fortress town of Iske Kazan is one of such enigmatic fortresses. Its significance is evident from numismatic study, which indicates that Iske Kazan might have struck its own coins, and it is quite possible that its fortification was connected to the appearance of a mint in the city. Moreover, the proximity of this fortress town to the territory populated by the Mari and Udmurts may also allow us to appreciate its history within the more general history of other border settlements.

The former townlet of Iske Kazan (which means "Old Kazan" in Tatar) on the Kazansu river is nowadays seen as one of the best preserved monuments of the republic of Tatarstan. Its roots likely predate the Mongolian period, emerging as a market town with some artisan activity, which was eventually fortified as a citadel. 
The settlement was located on a plateau on the right bank of the Kama, not far from the current villages Kamaevo and Tatarskaia Aisha in the Vysokogorskii district. Some scholars have long suggested that Kazan was founded by migrants from Iske Kazan [10]. Several researchers believe that the town originally carried the name of Ichke Kazan (which means "Inner Kazan" in Tatar) [12]. At the same time, most scholars reject the idea of Kazan as having been founded by outsiders, and suggest that Kazan was a town that had continually existed since Volga-Bulgar times, predating the conquest of the region by Batu Khan in 1236 and 1237 [39, p. 18-19]. Regardless of the exact link between Kazan and Ichke or Iske Kazan, the use of new sources may yield new insights into the history of Old or Inner Kazan. As one of these sources may serve a hitherto unknown map of Iske Kazan (Library number: Osn. op. 744) that is deposited in the Manuscript Department of the Russian Academy of Sciences' library in Saint-Petersburg, on which this essay's analysis focusses (see Illustration 1). As we can see from it, the map is called "Map of the old Tatar town of Iske Kazan, in Russian called Old Kazan". The map is said to have been drawn on 4 July 1770 (15 July 1770, according to the modern Gregorian Calendar). The map is hand-made and drawn on writing paper of 34 by 56 centimetres (within its cadres), in four colours. The scale is 30 sazhen' per inch (duim, an originally Dutch measurement meaning "thumb," showing the significant Dutch influence on cartography), or 1 centimetre to 2,520 centimetres according to the metric system, with four straight corners (see Illustration 1). On the map are depicted the territory of the town of Iske Kazan, indicated by the letter A (using the Roman script, evidently, another likely sign of the Dutch impact in this field); the place of the location of some stalls (for a market?), under the letter B; the profile of walls and the moat between them, under the letter $C$; the village of Kamaevo, under the letter D; and, finally, the little river of the Kazanka (Kazansu), under the letter E. While not explained in the caption, the map indicates the road to the Tatar village of Isha (currently, the Tatar settlement of Aisha).

The village of Kamaevo at the left bottom of the map shows geometrically planned streets and a church, while a fence surrounds it, with two gates at its southeast and north-east sides. The depicted course of the Kazansu is wholly different from what it is today, but a study of the course of the Kazansu over time from satellite pictures allows one to surmise that this course change has repeatedly occurred. Because of this, one cannot assume the course of the Kazansu in 1770 would have been the same as at the time of the construction of the ditch and the walls of Iske Kazan (somewhere in the two centuries before 1552).

The map's author can be identified with a fairly high degree of certainty. While any kind of written source incontrovertibly identifying him is missing, its precise dating allows us to suggest that in all likelihood its author was Nikolai Petrovich Rychkov (1746-1784), one of Russia's first ethnographers. Rychkov visited Kazan from 1 to 4 July 1770, about which sojourn he left a description in his travel account [42]. A year earlier Rychkov had visited a number of nearby settlements, which found reflection in his published work. It contains among other things further relevant information about the then state of medieval Tatar towns and contains maps of a number of places similar to our publication's map. The general style and method of the sketching of the fortification (walls and moat) on Iske Kazan's map is similar to maps of other Tatar towns Rychkov completed before his visit to Iske Kazan [43]. 


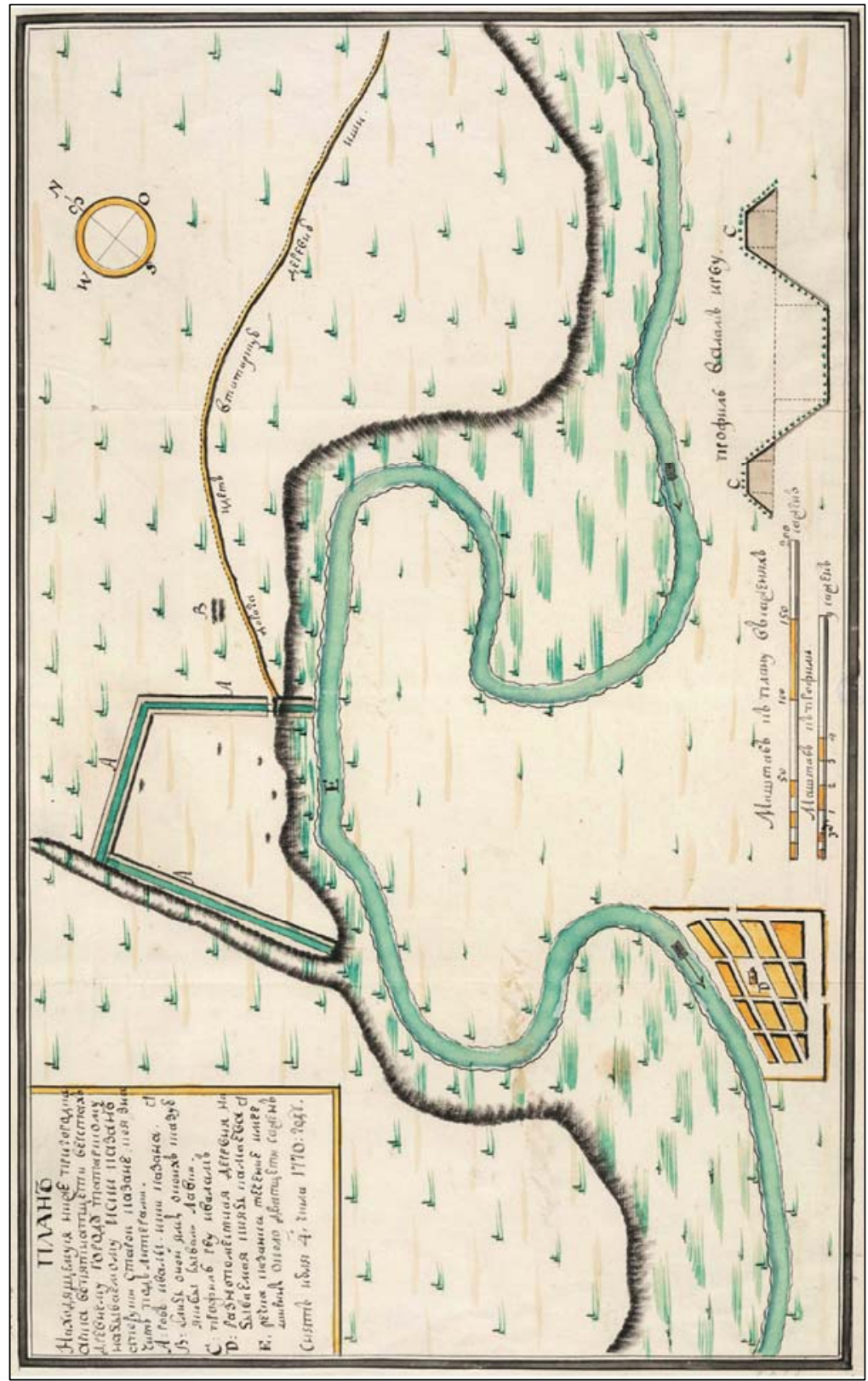

Illustration 1. Map of the Tatar town of Iske Kazan ("Plan drevnemu tatarskomu gorodu Iskikazan, a po russki nazivaemomu Staraia Kazan'. 1770 g.”. Manuscript Department, Library of the Russian Academy of Sciences, St. Petersburg)

(Library number: Osn. op. 744). Its handwritten legend reads:

Map of the Tatar town that is called Iske Kazan, or in Russian Old Kazan, located fifteen versts below the settlement of Arsk, on which the letters mean:

A - Moat and wall of Iske Kazan

B - Near one post about which it is said that there were market stalls

$\mathrm{C}$ - Profile of moat and wall

D - Village belonging to various owners, called Prince Kamaeva (Kniaz Kamaeva)

$\mathrm{E}$ - The rivulet Kazanka, which is about twenty sazhen' wide.

Sketched on 4 July 1770 
For unknown reasons, the map of Iske Kazan was not published by Rychkov, and has until now been overlooked by researchers. This map's key historical significance lies in its extremely precise depiction of the manner of the town's fortification, as well as its careful determination of the quantitative parameters of the structure and profile of the walls and the moat in between them. An analysis of the map allows us to scrupulously pinpoint the structure and dimensions of its medieval fortification.

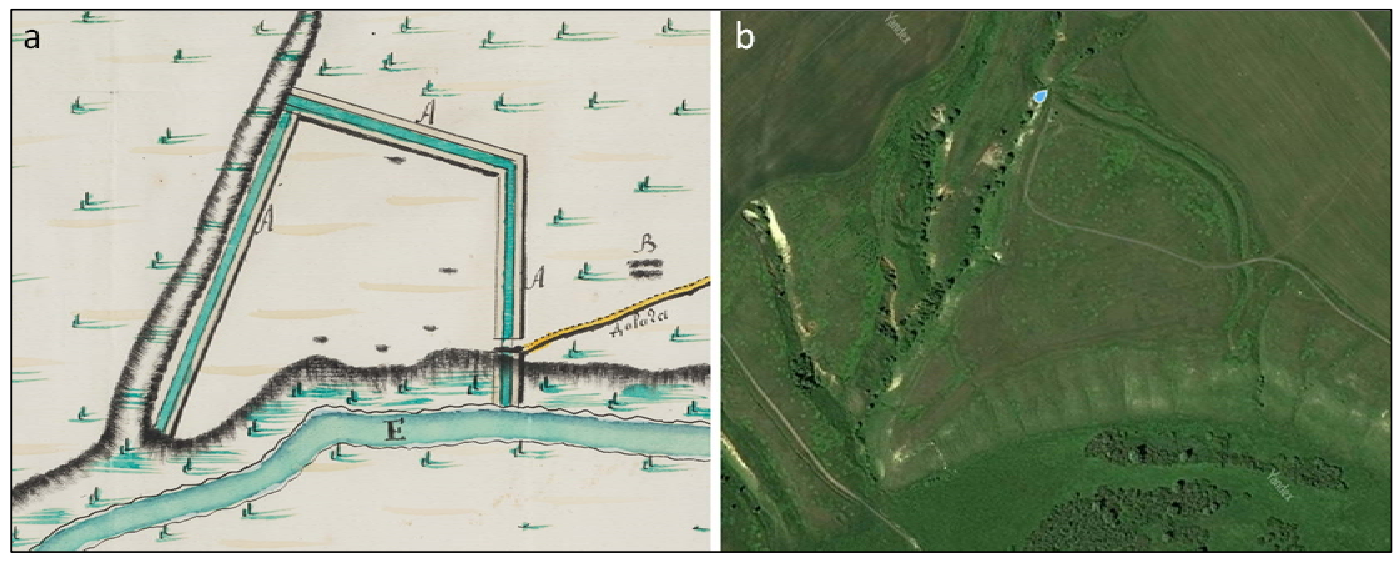

Illustration 2. Rychkov's 1770 map (a) and satellite picture (b) of same area (Yandex.ru maps service was used to obtain the satellite map)

Several scholarly works suggest that Iske Kazan was defended at the northside by two walls with a moat between them, although a part of these reinforcements are identified as an indistinguishable "northern wall" [17]. Similarly, the existence of a short southern defensive rampart is indicated, covering the promontory between the plateau along the Kazansu river and the ravine $[17$, p. $127 ; 10$, p. 138; 24]. Thus, the consensus in reconstructing the fortification of Iske Kazan was that it was based on two parallel systems of walls and moats, linked by opposite sides of the promontory to the north and south. Additionally, the existence or use of wooden fortification structures has been suggested, located both on the walls and on the edge of the ravine (west) and the plateau (east) [19].

The depiction of the town's fortification on the 1770 map, however, indicates a fundamentally different manner of the building of Iske Kazan's fortification. Judging from the nature of the rendition, at the moment that the sketch was made its defensive system survived to much a greater degree than today. The fortification it depicts appears to be a structure consisting of two trapezoid-shaped walls of practically similar height and width and a deep moat between the walls. Illustration 3 shows a fragment of the 1770 map, depicting the profile of these walls and the moat between them, as well as a graphic reconstruction allowing an estimate of the dimensions of the fortification's parts. 


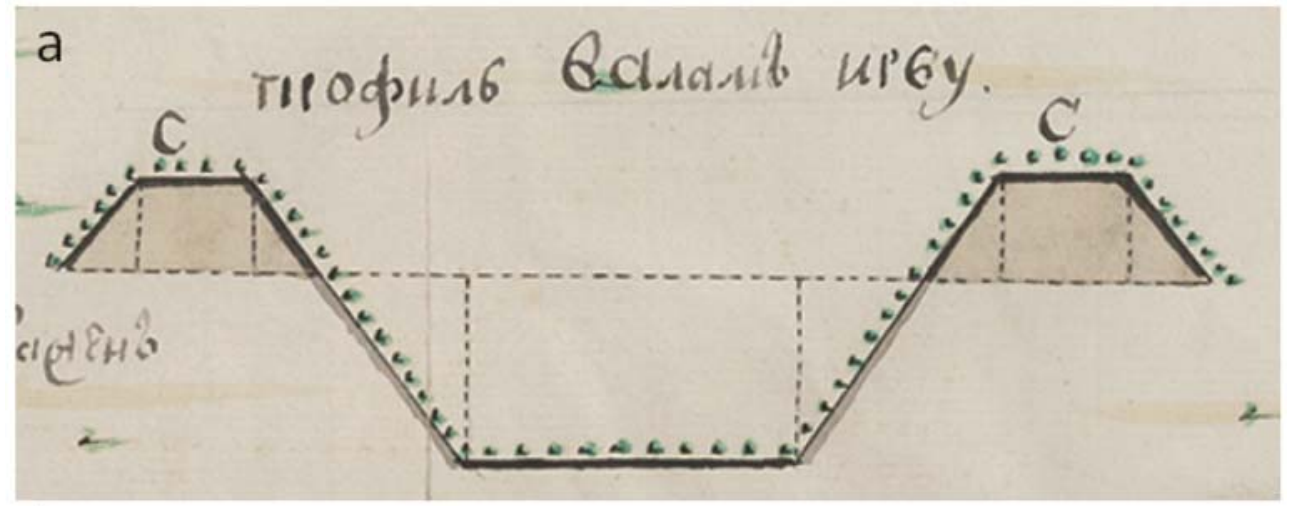

b

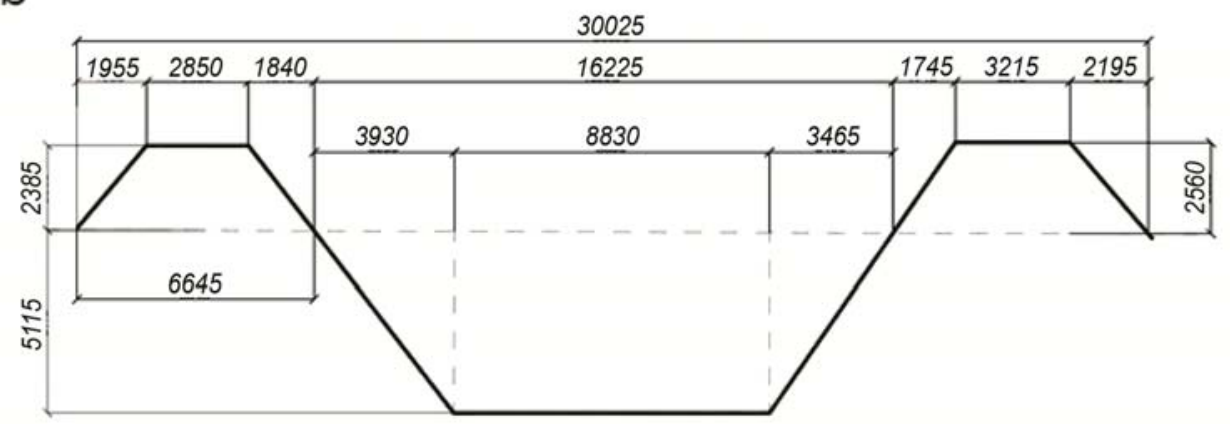

Illustration 3. Part of the 1770 map, depicting the walls-and-moat profile (a), and their graphic reconfiguration indicating its metric measurements (b)

In this way, the most apt term to describe the fortification of the town of Iske Kazan appears to be that of "wall-moat-wall". Table 1 allows to compare the dimensions of the wall-moat-wall defense, as indicated according to map's scale with contemporary dimensions from an earlier publication [17, p. 127].

Table 1

\begin{tabular}{|l|c|c|c|c|}
\hline \multirow{2}{*}{} & \multicolumn{2}{|c|}{ Gubaidullin [17] } & \multicolumn{2}{c|}{1770 Map } \\
\cline { 2 - 5 } & $\begin{array}{c}\text { Height (depth, } \\
\text { in metres) }\end{array}$ & $\begin{array}{c}\text { Width } \\
\text { (in metres) }\end{array}$ & $\begin{array}{c}\text { Height } \\
\text { (depth, } \\
\text { in metres) }\end{array}$ & $\begin{array}{c}\text { Width } \\
\text { (in metres) }\end{array}$ \\
\hline Inside wall & $2.5-3$ & $10-14$ & 2.4 & 6.6 \\
\hline Outside wall & $1-1.5$ & 6 & 2.6 & 7.2 \\
\hline Moat between walls & 3 & $10-14$ & 5 & 16 \\
\hline
\end{tabular}

Table 1 makes evident that, in the course of the more than 240 years that has passed after their depiction on the 1770 map, a partially unequal diminishing of the walls and growth in the height of the moat's soil has occurred. Today, the outside wall is almost twice as low and narrow as the internal wall, whereas they had almost the same height and width a quarter millennium ago. It should be noted that the lowering of the height of the walls and the lessening of the moat's depth has 
been accompanied by a significant widening of the internal wall, whereas the width of the outside wall somewhat has shrunk in comparison with 1770 . We apparently are dealing with uneven erosion here.

It was earlier noted that the initial depth of the moat was 4.6 to 4.8 metres, which is slightly less than Rychkov's height of 5 metres, but fully accords with a slow natural filling up of the moat, and appears to confirm the precision of Rychkov's measurements [5]. Furthermore, one cannot exclude the diminution of the external wall's height as part of a process to transfer soil for ploughing purposes outside of the settlement in the course of almost 250 years. Judging from the contemporary state of the inner wall, we suggest that the lowering of its height did not occur because of the wall's destruction, but because of the level of the ground's heightening caused by the cultivated soil that was adjacent to the wall. It is likely that, in a reconstruction of the baseline view of the fortification, it suffices to remove a part of the accumulated soil from the outside wall. Today the height of both walls is almost the same, if measured from the floor of the moat, even if, when measured from the top of the surface from the outside of the floor on the side of the outside wall, it is markedly lower than on the inside, which conforms to Gaibadullin's measurements [19, p. 174].

A reconstruction of the fortifications of Iske Kazan therefore needs to be based on the initial building of what were once earthen reinforcements, as depicted by Rychkov on his 1770 map. In a number of published works a graphic depiction of Iske Kazan is rendered, according to which the town was surrounded by walls and moat, in addition to which the outside wall had a wooden palisade, and the interior wall a closed wooden fence. Such a reconstruction, evidently, is based on an erroneous estimate of the dimensions of the outer and inner walls. Certainly, if the outside wall was considerably lower than the inner one, then such a reinforcement would have been logical, even if in this case, too, a question arises about the function of the moat, which instead of serving as an obstacle against those attempting to storm the town, would instead serve in effect as a hindrance for the transfer of the towns's defenders between its inner and outer fortifications. The written notes of Rychkov about the structure of the earthen fortification of Iske Kazan allows us to suggest that neither a wooden wall nor a palisade ever existed. In all likelihood, the fortification, consisting of two relatively low walls with a deep and wide moat between them was aimed at protecting the town from the enemy's cavalry and prevent its capture by stealth. During a well-organised siege using foot soldiers and siege equipment, such a fortification would not provide an adequate defence; it is, however, to be noted that the appearance of fortifications in Tatar towns coincides with a period of instability affecting the Golden Horde, during which the greatest danger for the towns were the mounted units of the competing claimants to supremacy in the Golden Horde, not fully equipped siege armies [27, p. 70]. The erection of Iske Kazan's fortification might also have been linked to the early phase of the "gunpowder revolution" of the fourteenth century, which saw the appearance of cannon among the Tatars. One might recognise a reflection of this in the absence of a forward line of defense composed of many walls, which had been typical of the previous period of the united Golden Horde.

The structure in itself reminds of the later fortification to which bastions would be added, which only appeared in Russia during Peter I's reign. Meanwhile, the Tatar tactics of exhausting the enemy through frequent diversionary sorties, known 
from the 1552 siege of Kazan, could be used with such a fortress as Iske Kazan's. One might draw a preliminary conclusion and distinguish Russian from Tatar fortifications and observe the absence of the more common wood-and-soil structure in this fortress [26]. When seen from the tactics that were in use, it is likely that a high observation tower existed to deliver signals to cavalry units or nearby fortresses. In other words, the fortifications of Iske Kazan that appeared in these conditions fulfilled the same role as Bolgar's fortification, which, according to recent scholarship also consisted of the wall-moat-wall system, and similarly lacked palisades, wooden fences, and towers [27, p. 66-70]. The only difference was that Bolgar was defended by one wall and a moat before it, and Iske Kazan by two walls with a moat between. A graphic depiction of the wall-moat-wall is given in our fourth illustration, which is accompanied by contemporary photographs of similar parts of Iske Kazan's fortification as they survive today. Little figures of people on foot and horseback have been added to illustrate the dimensions.

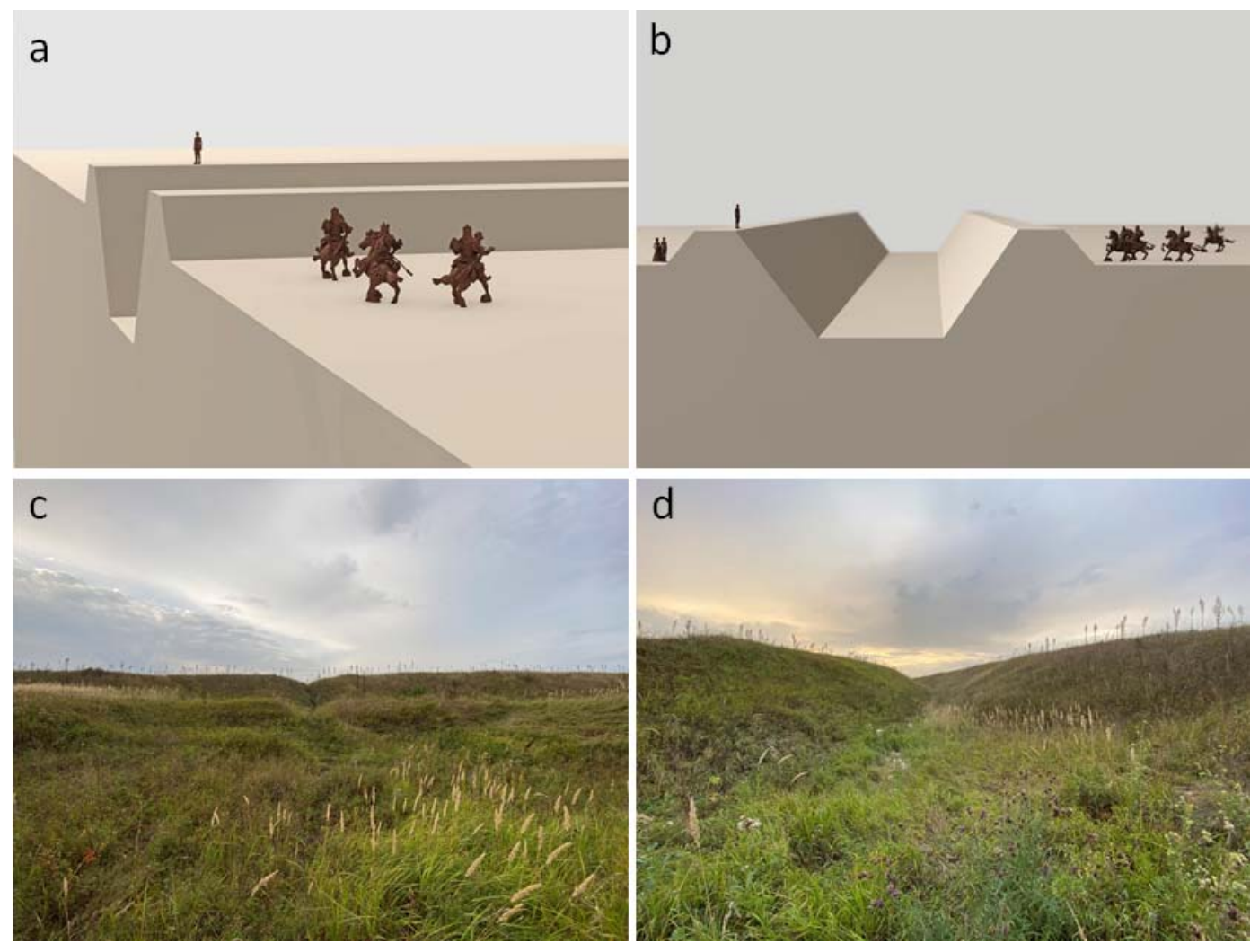

Illustration 4. Graphic reconstruction (a, b) and contemporary situation (c, d). The graphic illustrations were made by artist Niyaz Khaziakhmetov

Considering the character of the potential threat (heavy cavalry), it is tempting to suggest an analogy between the efficacy of Iske Kazan's fortifications and the contemporary way of building animal exhibition areas in zoos, which have a deep moat located between two walls of moderate height. Mammals cannot cross such obstacles, which makes the system very effective [2]. It is likely that such a concept made 
Iske Kazan's inhabitants develop a similar defensive mechanism to protect their town from hostile cavalry. Taking into account that the military organisation of the town's residents was more likely than anything based on a similar use of cavalry as their foe's, such a system of defence hindered an organised attack on its walls, for attacking horses could not overcome the moat, while archers (or possibly cannon) on the inner wall would quite effectively incur losses on the enemy's horses from their elevated position, as happened elsewhere in the warfare of this period, as at Crécy (1346), Poitiers (1356), or Agincourt (1415) in the Hundred Years' War.

Furthermore, a fast-paced attack by the enemy was impossible, as at any moment a counterattack by the defenders' cavalry might be launched. One might propose that in case of military necessity the defenders' cavalry might launch forays using temporary bridges or similar contraptions that could be thrown across the moat from anywhere within the town. The attackers would not have been able to use such a strategy as they would have to transport on foot equipment to build such bridge-like structures that could reach across to the town's moat. This would have been impossible, as such an effort would have been directly countered either by sorties by one of the defenders' mounted units, or by a rain of arrows from the archers, or fire from the town's artillery.

Such a system of urban defence would additionally allow the town dwellers to quickly depart in case of an overwhelming threat. Such a threat might be a raid by ushkuiniks (Volga or river pirates), who, evidently, would attack on foot. In case ushkuiniks succeeded to reach the town's walls unnoticed and get inside, the residents had the option to save their lives by traversing the walls and moat almost anywhere. There is no information about an ushkuinik attack on Iske Kazan, but several other of the Golden Horde's Tatar towns were certainly subject to ushkuinik attacks, after which they almost immediately recovered from them. It is possible that this recovery was made possible because the town population was able to evacuate during a surprise raid by ushkuiniks, whose number and ferocity might not allow for any other way of dealing with them.

The fortification system of Iske Kazan in 1770 appears to be rectangular. Some of its elements still survive today (the northern and north-east part of the wall-moat-wall system), but its most interesting detail is the partially destroyed wall-moat-wall system in the west, along the edge of the ravine (which is today called the Lesnoi Ovrag, or wooded ravine). It is obvious that the outside wall in this sector has not everywhere survived, and in many places the widening of the ravine has led to the destruction of the outside wall of the defensive system. The moat and internal wall, however, as depicted on the 1770 map, still appear commensurate with the surviving elements (the north and north-eastern wall-moatwall) in terms of their dimensions, especially those located close to the southern part of the plateau along the Kazansu river's shore. The question therefore arises why there was a need for the establishment of a moat along the western border of the town: Why was it necessary to build this sort of fortification in the direct proximity of an existing ravine that seems nowadays rather deep? The only explanation might be the later appearance of the ravine as the result of developing erosion, while initially, when the fortification was erected, the western ravine did not exist, or appeared yet as an undeep depression. In order to establish the exact time of the ravine's appearance (or deepening) additional geological investigations are necessary, but our cartographic material allows us to establish that, in the period from 
1770 until today, the western ravine at Iske Kazan has significantly increased. If in 1770 the western ravine has one track, then in 2019 a minimum of three tracks had formed, as well as whole array of small branches, indicating active erosion (see Illustration 2). In sum, erosion led to the formation of ravines that are today located east of the city, which on Rychkov's map are not indicated. This allows us to surmise that changes occurred in the topography of the territory of Iske Kazan from the moment of the end of its existence.

Linked to the system of walls along the western borders of Iske Kazan is the unexplained function of the southern wall mentioned previously [17]. If we imagine that several wooden fortifications stretched out along the western ravine and the plateau above it, then they must have been linked at the utter southern corner of the promontory. It is impossible to imagine a southern wall intended to withstand an attack on the town beyond the borders of the rest of the fortification. Furthermore, on Rychkov's 1770 map a southern wall is absent. It leads for us therefore to suggest that a southern wall was not a part of the defensive works of Iske Kazan. It must have been erected after 1770 .

Not less interesting is the south-eastern part of Iske-Kazan's fortifications indicated on the 1770 map (see Illustration 1). It indicates how the wall-moat-wall system did not merely exist at the elevated plateau, but also descended downward, to the shore of the Kazanka. In previous works on the town's fortifications, the wall-moat-walls were only indicated as existing at the higher levels, on the promontory; moreover, they suggested that the town had a division into a "citadel" and a "suburb" (posad) and that the higher part of the town (the alleged citadel) was not linked to the posad located on the washland of the Kazansu river [32]. Rychkov's 1770 map shows, however, that the town's fortification was not just stretching out along the promontory, but also reached downward onto the floodplain of the Kazansu river. Clearly, the town was not divided into a citadel and suburb, but was surrounded by one system of walls in its entirety. It is not clear from the map whether a fortification existed on the left shore of the Kazansu river, but we cannot dismiss this possibility. It is additionally possible that the river crossed through the town's fortifications. Fortifications on the river's left shore might not have survived because of flood destruction, or a change of course of the Kazansu river. Neither can one exclude the possibility that the fortification only existed on the right bank of the river along the shoreline, which might have guaranteed the inhabitants a defensive option through an exit by way of the river in case of attack. For this, an access route onto the plateau must have existed, which linked the town's lower part with its higher section. It is likely that such an access route would have been located within the fortified walls and would not have needed an entry gate into the fortified wall.

Unfortunately, the map does not indicate a similar descent of the wall system at the south-western part of the town, which might be explained by its decay by 1770. No sort of fortification along the Kazansu river shores is indicated either, but it would be naive to suggest that in the time that had passed since the town's destruction in the middle of the sixteenth century such shoreline buildings must have been preserved. Already by 1770, the annual spring flooding as well as the periodic change in the river's course may have led to the absence of any visible sign of the fortifications. That does not exclude the possibility, however, of the discovery of such remnants in the course of further archeological investigations. 
It is interesting to ponder the manner of access into the town from the landside. On Rychkov's map we see only one opening that may have functioned as a gate. This entrance appears to be an eight-metres-wide gap between the walls, located quite closely to the edge of the plateau along the Kazansu river shore. Judging from the lack of other entrances through the wall system, that opening must be a part of the original fortification structure. The entryway survives until today, with the same width (ca. 9 metres) as on the 1770 map. It is unclear how the gate might have been mounted, but comparing the depiction of the entrance on Rychkov's map with the current situation allows us to suspect that some of it survives undamaged, and archeological research might allow us to understand the way of building of access ways in Tatar fortifications.

Previously a hypothesis has been published that argues that the entrance into Iske Kazan was via a four-to-eight-metres wide road, located along the western slope of the highest part of the fortress [18]. Judging from this author's sketch and graphic depiction, the entryway into town had to be located close to the corner that was formed by the western and northern wall-moat-wall system. It is, however, easily visible on the 1770 map that along the entire length of the higher part of the Iske Kazan fortress only entrance into town exists (of a width of about 9 metres), located in its southeastern part, close to the place where the fortification descends toward the Kazansu river. On the basis of its 1770 state as indicated on Rychkov's map of Iske Kazan, we can reject the possibility of the use of a corner of the ravine as an entryway into town at the time that its wall-moat-wall fortification functioned as its defence.

Unfortunately, at the moment we do not have any precise date for the foundation of the town of Iske Kazan, and any estimates about the beginnings of its settlement are made on the basis of the findings of archeological excavations or of legends and traditions. The existence of a road along the edge of the Lesnoi Valley is mentioned by R.G. Fakhrutdinov, but the map that we hereby publish questions the contemporary or synchronous existence (and practical use) of the road with the fortification system [10, p. 146]. If we hypothesize that the appearance of the Lesnoi Ravine in its current shape occurred only after the city had been abandoned (that is, after the middle of the sixteenth century), then the erection of the defensive walls made this road lose any practical significance. Nonetheless, one cannot exclude the possibility that this road existed in the time before the building of the fortifications.

The structure of Iske Kazan's fortification and the nature of its location in many ways seems similar to that of the town of Bolgar, which is situated on a similar plateau, and does not have natural reinforcements at the land side. It is known that Bolgar, like other cities of the Golden Horde, initially had no more than some sort of simple defensive works that were built in the second half of the fourteenth century, during a politically unstable period that affected its government. The map here reproduced allows us to ponder the timing of the fortification's building at Iske Kazan, as well as a possible foundation and existence of the town in the period before the second half of the fourteenth century.

Alas, the written description of Iske Kazan that N.P. Rychkov left us is hardly anything more concrete than a legend about the origins of the town [42]. In addition, in comparison to his previous descriptions of other towns, he dedicates far less space to describe the current state of the abandoned town of Iske Kazan [43]. Rychkov 
notices that the territory of the town is enclosed within the borders of the walls that survive; in addition, that he did not encounter any stone buildings or other ruins, while, after visiting a number of medieval Tatar settlements in the Trans-Kama region (Kandaly, Bilyar, Chibash), he does discuss their stone structures in various states of preservation. On his map a sort of Yam (postal or supply station) is noted, where stalls are situated, but, in the description of Iske Kazan, information about the Yam or the stalls is absent. Perhaps the market (bazar) of the old town had been located there, about which Rychkov found out through his conversations with the local residents. Finally, an entry way into the town is noted on the map that links Iske Kazan with the road to the contemporary Tatar village of Aisha.

In some ways, of course, definitive conclusions cannot be made about our findings yet, even if our findings may correct some erroneous ideas about the first capital of the Kazan khanate. Further geological (through soil samples), or archeological (carbon-dating), investigations might lead to answering some of the questions, as might the discovery of new written sources on Iske Kazan, in its heyday or its afterlife. It remains impossible to assess the town's exact importance in the unsettled period between the unraveling of a unified Golden Horde and the successor state that arose from its ashes, whose contours took clear shape toward 1450. Whereas Rychkov's map allows us to make a decent guess at the rationale behind Iske Kazan's defensive set-up, we do not know whether it proved effective in keeping out its enemies, or avoiding the devastation of a sack. We do not know how the defensive system was linked, with fortifications at the bottom of the promontory along the river or even across the river. And we do not know why precisely a place that at one point seems to have been a thriving centre of mid-Volga Muslim culture faded, giving way to its eventually far larger namesake located much closer to the Volga. Nor do we know why and how the Muslim population and the town of Iske Kazan as such subsequently entirely disappeared from this spot, merely leaving behind the few remnants of their former glory that we can see today.

Evidently, we may surmise that for perhaps two generations or so Iske Kazan proved to be the ideal settlement to flourish in the context of its turbulent times, from the late fourteenth to the mid-fifteenth century. We can also propose that further research into archaeological, written, or other (geological, chemo-biological, genetic) sources may yield some further answers about this chapter in the history of a Eurasian region that has been a fertile crossroads, on which a startling number of ethnocultural communities met, who often interacted peacefully and sometimes violently.

The authors would like to express their gratitude to Mr. Niyaz Khaziakhmetov for the graphical 3-D reconstruction and Dr. Anna Dzhioeva for technical help. This paper has been supported by the Kazan Federal University Strategic Academic Leadership Program (Rawil Fakhrullin). 


\section{REFERENCES}

1. Balkind N. A Model Republic? Trust and Authoritarianism on Tatarstan's Road to Autonomy. Unpubl. Ph.D. Diss. University of North Carolina at Chapel Hill, 2009.

2. Bigalke R. The use of moats in zoological gardens. International Zoo Yearbook. 1961, no. 1, pp. 62-66.

3. Black J.L. G.F. Müller and the Russian Imperial Academy. Montréal; Kingston: McGill-Queen's University Press, 1986.

4. Boterbloem K., Aidarova G., Fakhrullin R. Istoriko-arkhitekturnyi analiz izobrazheniia Kazani gollandskim masterom Kornelisom de Breinom (1703 g.) [A historical-architectural analysis of the panoramic image of Kazan by Cornelis de Bruijn]. Vestnik Sankt-Peterburgskogo universiteta [Saint Petersburg University Bulletin]. 2020, no. 2, pp. 566-584. (In Russian)

5. Burkhanov A.A. Zolotoordynskie pamiatniki Povolzh'ia: Itogi i perspektivy sokhraneniia i ispol'szovaniia [Golden Horde monuments in the Volga region: Sources and perspectives of preservation and utilization]. Istoriya i sovremennost' [History and Modernity]. 2007, no. 1, pp. 85-108. (In Russian)

6. The Cambridge History of Inner Asia: The Chingissid Age History of Inner Asia. Di Cosma N. et al. (eds). Cambridge: Cambridge University Press, 2009.

7. Coehoorn M. Nieuwe Vestingbouw, Op een natte of lage Horisont.... Leeuwarden: Hendrik Rintjes, 1685. (In Dutch)

8. Çolak I. Secularization of the Muslim Mind: Defining the Muslim Reformation among Volga-Urals Muslims (between late eighteenth and early twentieth centuries). Unpubl. Ph.D. Diss. Indiana University, 2011.

9. Driessen-van het Reve J. De Kunstkamera van Peter de Grote. De Hollandse inbreng. Hilversum: Verloren, 2014. (In Dutch)

10. Fakhrutdinov R.G. Ocherki po istorii Volzhskoi Bulgarii [Essays on the History of Volga Bulghary] Moscow: Nauka, 1984. (In Russian)

11. Frank A.J. Islamic Historiography and the "Bulghar" Identity among the Tatars and Bashkirs of Russia. Leiden: Brill, 1998.

12. Galliam R.G. Pervonachalnaia stolitsa zemli Kazanskoi (voprosy khronologii, "stolichnogo" statusa i istorikokul'turnogo znacheniia pozdnesrednevekovogo gorodkakreposti "Ychki Kazan'/Ichki Kazan"” v srednem basseyne r. Kazanka) [The first capital of the lands of Kazan (chronological problems, the status of "capital" and the culturalhistorical significance of the late medieval fortress townlet of "Ychki Kazan'/Izchki Kazan" at the middle reaches of the River Kazanka]. Nauchnyi Tatarstan [Scientific Tatarstan]. 2015, no. 3, pp. 60-67. (In Russian)

13. Geloof alleen je eigen ogen: Een actuele kijk op de anatomische preparaten van Frederik Ruysch (1638-1731). Driessen-van het Reve J., Bleker O. (eds). Amsterdam: Lias, 2017. (In Dutch)

14. Geraci R.P. Window on the East: Ethnography. Orthodoxy, and Russian Nationality in Kazan, 1870-1914. Unpubl. Ph.D. Diss. University of California at Berkeley, 1995.

15. Giuliano E. Paths to the Decline of Nationalism: Ethnic Politics in the Republics of Russia. Unpubl. Ph.D. Diss. University of Chicago, 2000.

16. Guadagnolo G. Creating a Tatar Capital: National, Cultural and Linguistic Space in Kazan, 1920-1941. Unpubl. Ph.D. Diss. University of North Carolina, Chapel Hill, 2016.

17. Gubaidullin A.M. Fortifikatsiya v Srednem Povolzh'e v pervoy polovine XVI v. [Fortification in the Middle-Volga region in the first half of sixteenth century]. Arkheologiia Evraziiskikh stepei [Archaeology of the Eurasian Steppes]. 2019, no. 3. (In Russian)

18. Gubaidullin A.M. O tipakh sredneverkhovykh vorotnykh proezdov na territorii Srednego Povolzh'ya [On the types of middle-height gate entrances in the Middle-Volga 
region]. Voennoe delo Zolotoy Ordy: Problemy i perspektivy izucheniya. Materialy Kruglogo stola, provedennogo v ramkakh Mezhdunarodnogo Zolotoordynskogo Foruma [Warfare of the Golden Horde: Problems and Prospects of Study. Proceedings of the Round Table Held within the Framework of the International Golden Horde Forum]. Kazan: Foliant, 2011, pp. 78-81. (In Russian)

19. Gubaidullin A.M. Sravnitel'nyy analiz fortifikatsii Kazanskogo i Sibirskogo khanstv [A comparative analysis of the fortification of the Kazan' and Siberian Khanates]. Povolzhskaya Arkheologiya [The Volga River Region Archaeology]. 2018, no. 4, pp. 173181. (In Russian)

20. Halperin Ch. Russia and the Golden Horde: The Mongol Impact on Medieval Russian History. Bloomington: Indiana University Press, 1987.

21. Halperin Ch. The Tatar Yoke. Second ed. Bloomington: Slavica, 2009.

22. Jackson P. The Mongols and the West, 1221-1410. Second ed. New York: Routledge, 2018.

23. Jacob M. The Scientific Revolution. Second ed. New York: Bedford-St. Martin's, 2018.

24. Kalinin N.F., Khalikov A.Ch. Itogi arkheologicheskikh rabot za 1945-1952 gg. [Results of the Archaeological Work from 1945 to 1952]. Kazan: Tatknigoizdat, 1954. (In Russian)

25. Kivelson V. Cartographies of Tsardom: The Land and Its Meaning in seventeenthcentury Russia. Ithaca: Cornell University Press, 2006.

26. Koval V.Iu. Metodika izucheniia valov drevnerusskikh gorodov i popytka rekonstruktsii drevnikh oboronitel'nykh sooruzheniy v nature [Methodology of the study of walls of Old-Russian towns and an attempt to reconstruct ancient defensive structures in nature]. Arkheologiya Podmoskov'ya [Archaeology of the Moscow Region]. 2020, no. 16, pp. 401-414. (In Russian)

27. Koval' V.Iu., Rusakov P.E. Issledovaniya fortifikatsii goroda Bolgara v 20142015 godakh: Materialy $i$ issledovaniia po arkheologii Velikogo Bolgara [Investigations of the Fortification of the Town of Bolghar in 2014 and 2015: Materials and Research regarding the Archaeology of Ancient Bolghar]. Moscow; Kazan: Institut Arkheologii RAN, 2018, vol. 2. (In Russian)

28. Kugorn M. baron von (Menno van Coehoorn). Novoe krepostnoe stroenie na mokrom ili nizkom gorizonte.... [New Fortress Building on a Wet or Low-Lying Plane...]. Shafirov M., Brius I. (eds). Moscow, 1709. (In Russian)

29. Langins J. Conserving the Enlightenment: French Military Engineering from Vauban to the Revolution. Cambridge, MA: MIT Press, 2003.

30. Morgan D. The Mongols. London: Blackwell, 1986.

31. Naarden B. Nicolaas Witsen en Tartarye. Available at: http://resources.huygens. knaw.nl/retroboeken/witsen/dutch_intro.pdf. (accessed: 4.11.2020). (In Dutch)

32. Nadyrova Kh.G. Razvitie gradostroitel'noy kul'tury Kazanskogo khanstva (1) [Developments in the city-building culture of the Kazan' Khanate]. Zolotoordynskoe obozrenie $=$ Golden Horde Review. 2014, no. 2, pp. 147-171. Available at: https://elibrary.ru/item.asp?id=23168597 (accessed 2.11.2020). (In Russian)

33. Ostrowski D. Muscovy and the Mongols: Cross-Cultural Influences on the Steppe Frontier, 1304-1589. Cambridge: Cambridge University Press, 1998.

34. Pirenne H. Medieval Cities: Their Origins and the Revival of Trade. Princeton: Princeton University Press, 1956.

35. Pirenne H. Les villes du Moyen Âge. Bruxelles: Lamartin, 1927. (In French)

36. Plan drevenemu tatarskomu gorodu Iskikazan, a po russki nazyvaemomu Staraya Kazan'. 1770 g. [Map of the ancient Tatar town of Iske Kazan, in Russian called Old Kazan']. Manuscript Department, Library of the Russian Academy of Sciences. St. Petersburg. (In Russian) 
37. Mapping the Republic of Letters. Available at: http://republicofletters.stanford.edu/ (accessed: 2.11.2020).

38. Romaniello M. The Elusive Empire: Kazan and the Creation of Russia, 15521671. Madison: University of Wisconsin Press, 2012.

39. Rorlich A.-A. The Volga Tatars: A Profile in National Resilience. Second ed. Stanford: Hoover Institution Press, 2017.

40. Ross D. Tatar Empire: Kazan's Muslims and the Making of Imperial Russia. Bloomington: Indiana UP, 2020.

41. Rudenko K.A. Istoriya arkheologicheskogo izucheniya Volzhskoy Bulgarii (Xnachalo XIII v.) [The History of the Archaeological Study of Volga Bulgharia (from the tenth to early seventeenth centuries)] Kazan: RTsMKO, 2014. (In Russian)

42. Rychkov N.P. Prodolzhenie Zhurnala ili Dnevnik zapisok puteshestviya po raznym provintsiyam Rossiyskogo gosudarstva, 1770 godu: Dokumental'no-khudozhestvennaya literatura [Continuation of the Journal or Diary of Notes of Journeys through Various Provinces of the Russian State in the Year 1770: Documentary-Artistic Literature]. St. Petersburg: Pri Imperatorskoy Akademii Nauk, 1772. (In Russian)

43. Rychkov N.P. Zhurnal, ili Dnevnye zapiski puteshestviya kapitana Rychkova po raznym provintsiyam Rossiyskogo gosudarstva, 1769 i 1770 gody [Journal, or Daily Notes of the Journeys by Captain Rychkov through Various Provinces of the Russian State, in 1769 and 1770]. St. Petersburg: Pri Imperatorskoy Akademii Nauk, 1770. (In Russian)

44. Strahlenberg P.J. von. Das Nord- und Ostliche Theil von Europa und Asia... Stockholm: Strahlenberg, 1730. (In Swedish)

45. Tuna M. (Ozgur). Imperial Russia's Muslims: Inroads of Modernity. Unpubl. Ph.D. Diss. Princeton University, 2009.

46. Vermeulen H. Before Boas: The Genesis of Ethnography and Ethnology in the German Enlightenment. Lincoln: University of Nebraska Press, 2015.

47. Vitsen N. [Nicolaes Witsen]. Severnaya i Vostochnaya Tartariya [North and Eastern Tartary]. 3 vols. Kopaneva N.P., Naarden B. (eds). Amsterdam: Pegasus, 2010. (In Russian)

48. Werth P.W. Subjects for Empire: Orthodox Mission and Imperial Governance in the Volga-Kama Region, 1825-1881. Unpubl. Ph.D. Dss. University of Michigan, 1996.

About the authors: Kees Boterbloem - Ph.D. (History), Full Professor, History Department, University of South Florida (4202 East Fowler Avenue, SOC 107, 33620-8100 Tampa, Florida, USA). E-mail: cboterbl@usf.edu

Almaz N. Khabibullin - civil engineer, the chief architect of LLC “AvanProect". E-mail: almaz-hab@mail.ru

Rawil F. Fakhrullin - Dr. Sci. (Biology), Chief Research Fellow, Institute of fundamental medicine and biology, Kazan Federal University (18, Kremlevskaya Str., Kazan 420008, Russian Federation). E-mail: kazanbio@gmail.com 


\title{
КАРТА ГОРОДА ИСКЕ КАЗАН НИКОЛАЯ РЫЧКОВА, 4 ИЮЛЯ 1770 Г.
}

\author{
К. Ботерблум ${ }^{1}$, А.Н. Хабибуллин ${ }^{2}$, Р.Ф. Фахруллин ${ }^{3}$ \\ ${ }^{1}$ Университет Южной Флориды \\ Тампа, США \\ cboterbl@usf.edu \\ ${ }^{2}$ ООО «АванПроект» \\ Казань, Российская Федерачия \\ ${ }^{3}$ Институт фундаментальной медицины и биологии, \\ Казанский федеральный университет \\ Казань, Российская Федерация \\ kazanbio@gmail.com
}

Цель исследования: в работе осуществлен анализ ранее неизвестной карты города Иске Казан, находящейся в фондах отдела рукописей Библиотеки Российской академии наук (г. Санкт-Петербург), составленной Н.П. Рычковым в 1770 году. Произведена графическая реконструкция фортификационных укреплений, позволявших защитить город от врагов в неспокойную эпоху распада Золотой Орды и последующего возникновения Казанского ханства. Кроме того, анализируются вероятные побудительные мотивы Н.П. Рычкова, оставившего несколько весьма подробных карт городов Волжской Булгарии и Золотой Орды.

Материалы исследования: сравнивая данные карты Н.П. Рычкова с археологическими находками и с соответствующей историографией, авторы помещают карту в ее исторический контекст, размышляют о ее значении и выдвигают предположения о причинах создания этой карты в 1770 году.

Результаты и научная новизна: судя по анализу информации, приведенной на карте, предыдущие реконструкции укреплений города Иске Казан не соответствуют действительности. Город был защищен довольно необычной фортификационной системой, состоящей из двух валов практически равной высоты и достаточно глубокого и широкого рва между ними, что исключает применение каких-либо дополнительных укреплений в виде городней или частокола. Вероятно, такая конструкция укреплений позволяла предотвратить любой штурм со стороны кавалерии. Такой способ защиты представляется в высшей степени подходящим к неспокойным условиям, преобладавшим в Волго-Камском регионе около 1400 года, и к военному искусству, которое практиковалось в этом регионе. В статье дополнительно указывается, почему эта карта была сделана в 1770 году, и как это связано с общим желанием правительства Романовых гораздо точнее узнать о том, как жили его подданные. Этот импульс возник в результате введения в царствование Петра I западноевропейского научного мировоззрения, которое уделяло гораздо больше внимания реалистическому пониманию природы и культуры. Российская академия наук организовала с 1720-х годов множество научных экспедиций, которые в определенной степени напоминают путешествия географических открытий, для составления карт царской империи, частью которой были путешествия Рычкова. По всей видимости, подобные миссии по установлению фактов постепенно позволили центральному правительству в Санкт-Петербурге усилить свою власть над подданными народами.

Ключевые слова: Золотая Орда, Казанское ханство, Иске Казан, Н.П. Рычков, научная революция, Respublica literaria, археология, картография, фортификация

Для цитирования: Boterbloem K., Khabibullin A., Fakhrullin R. Nikolai Rychkov's Map of Iske (Inner or Old ) Kazan of 4 July 1770 // Золотоордынское обозрение. 2021. T. 9, № 3. C. 593-610. DOI: 10.22378/2313-6197.2021-9-3.593-610 
Сведения об авторах: Корнелис Ботерблум - Ph.D. (история), профессор кафедры истории, Университет Южной Флориды (4202 East Fowler Avenue, SOC 107, 33620-8100 Тампа, Флорида, США). E-mail: cboterbl@usf.edu

Алмаз Наилевич Хабибуллин - инженер-архитектор, главный архитектор ООО «АванПроект». E-mail: almaz-hab@mail.ru

Равиль Фаридович Фахруллин - доктор биологических наук, главный научный сотрудник, Институт фундаментальной медицины и биологии, Казанский федеральный университет (420008, ул. Кремлевская, 18, Казань, Российская Федерация). E-mail: kazanbio@gmail.com

Поступила 06.05.2021 Принята к публикаџии 20.08.2021 Опубликована 29.09.2021 